\title{
The influx of high-income foreign nationals and the housing market in a developing country: A case study of Suzhou Industrial Park, China
}

\author{
Dr. Hyung Min Kim \\ Lecturer, Faculty of Architecture, Building and Planning, The University of Melbourne, \\ Australia \\ E hyungmin.kim@unimelb.edu.au
}

Department of Urban Planning and Design, Xian Jiaotong-Liverpool University, China

Title - The influx of high-income foreign nationals and the housing market in a developing country: A case study of Suzhou Industrial Park, China

\begin{abstract}
Increasingly globalising human and capital mobility has created new dynamics to the housing market. Foreign nationals, strengthened by inflows of foreign direct investment, have appeared in major Chinese cities. However, little scholarly attention has been paid to the impact of foreign nationals on the China's housing market. By using a case study of Suzhou, this research investigates the following research questions: how are foreign nationals associated with housing price increases in a globalising city? Where and why these impacts have been felt? This research conducted a survey questionnaire with 508 expatriate foreign nationals and built housing price datasets in Suzhou. A consumer theory provides a framework to understand different housing consumption behaviours of heterogeneous socio-economic groups. Findings represent that expatriate foreign nationals played a key role in a high-end housing market due to their higher income levels and housing subsidies provided by their employer. They tended to form ethnic communities in a prime location to better access languagespecific services and quality amenity facilities.
\end{abstract}

Keywords: Foreign nationals; housing market; ethnic communities; Suzhou Industrial Park 


\section{Introduction}

One of the major driving forces to reshape contemporary housing markets is global human and capital mobility. Growing volumes of international migration and capital movements have led to greater interest in the housing market in globalising cities. Cities with a long history of international immigration, mostly in western Anglophone countries, have experienced foreign home ownership, often causing concerns about housing affordability (Rogers and Dufty-Jones, 2015, Rogers et al., 2015, Edgington, 1996, Ley, 2017). Furthermore, the expansion of global influence into the housing market has been observed in non-Western countries such as South Korea (Kim, 2017a, Kim et al., 2015), Vietnam (Jung et al., 2013) and Singapore (Lim et al., 2002) in which each institutional setting varies.

Chinese cities have also joined the global market, leading to the restructuring of their housing sectors. These impacts have been felt primarily via rental arrangement by foreign nationals associated with corporate business activities in Chinese cities rather than real estate development by developers or housing purchase by individual investors. In favour of economic growth and technology transfer, Chinese cities have relied upon Foreign Direct Investment (FDI) channelled through multinational corporations (MNCs). MNCs have established their production functions in China to benefit from low labour costs and affordable land prices. Entrepreneurialism local governments provided incentives to MNCs (Wei et al., 2012, He, 2003, Yang and Hsia, 2007). While MNCs bring their technology via expatriate professionals, China's city-regions have provided abundant labour forces, mostly associated with rural-to-urban migration, and industrial land converted from rural land use. This research conducted a questionnaire survey with 508 foreign nationals and built a housing price dataset with 282 apartment complexes in a focal city, Suzhou, China to analyse new dynamics in the housing market.

The number of Foreign Invested Enterprises (FIEs) increased from 84,000 in 1992 to 440,000 in 2012 or more than a 5-fold increase over the twenty years (National Bureau of Statistics of China). Not only business sectors, but education has facilitated inflows of foreign nationals. With demand for English education becoming increasingly high, there are a growing number of language teachers. With tertiary education becoming more and more globalised, the number of international academic staff is on the increase, too. Obviously, some self-employed businessperson tapped into the Chinese market.

Despite the increasing volume of foreign nationals and their evident consequences to the China's housing market, little research has focused on the exploration of the dynamic changes in the housing sector. This research, therefore, addresses the following research questions: how are foreign nationals associated with housing price increases in a globalising city? Where and why this impact has been felt?

This paper is structured as follows. First, a literature review addresses dynamics of the housing market in a globalising city, urban policy for FDI inflows, and a consumer theory in the context of the presence of heterogeneous socio-economic classes. It also provides contextual backgrounds about the China housing market to understand institutional settings and outlines research questions and hypotheses. Second, data collection methods are described. Third, a background of the focal city, Suzhou, is provided with an emphasis on housing and entrepreneurism strategies. Fourth, a profile 
of Suzhou foreign nationals is provided from the survey. Fifth, empirical findings are presented corresponding to the hypotheses. Finally, some conclusions are made.

\section{Literature Review}

\section{Dynamics of the housing market in a globalising city}

Due to the relaxation of regulations on cross-border activities and advancements in transport technology, flows of people, products, capital and information have been accelerated (Harris, 1997). Firms have sought out low-cost production sites mostly in favour of affordable land, cheap labour costs, and access to the global market (Hodos, 2002, Dunning, 1998). China has emerged into the second largest recipient of inward FDI after the USA since the mid-1990s. Strategic approaches to the open door policy triggered MNCs to look into Chinese production sites while Chinese regions provided abundant cheap labourers and local governments inspired by entrepreneurism were proactive in offering industrial land (Fan, 2002, Ma and Wu, 2005).

The accumulation of global capital has been observed in the property sector in advanced capitalist economies in which surplus capital has been converted from the primary capital circuit to the secondary circuit of the built environments (Harvey, 1982). The integration of cities' economies to the world market tied up with neoliberalism has heated up property markets directly via property sales and development and indirectly via rentals of space. The global capital accumulation was manifested in commercial office buildings, called 'towers of capital' (Lizieri, 2009). $38-44 \%$ of the global commercial property transactions were completed by cross-border investors in the period 2008 - 2011 (Kim et al., 2015). Housing is also considered as a financial asset by property investors. Foreign home ownership has been pervasive in countries with high numbers of immigrants and tourists such as the USA, Australia and Canada often facilitated via ethnic networks (Gutstein, 1990). The Japanese were active in outward real estate investment in selected gateway cities and tourist cities such as Los Angeles, New York, Hawaii, and Gold Coast (Edgington, 1996). Chinese housing investors have appeared as a key player in housing development and investment strengthened by Chinese immigration. Their proactive investment has raised a concern about housing affordability of the locals (Rogers and Dufty-Jones, 2015, Rogers et al., 2015). In Vietnam, since an open door policy called Doi Moi in 1986, the government has gradually deregulated foreign activities; foreign property ownership was allowed in 2009 (Jung et al., 2013). Foreign developers from Taiwan, Korea, Japan and Singapore have participated in apartment development projects in Vietnam (Jung et al., 2013). Although foreign direct investment in real estate including housing is growing in volume, the impact of the influx of foreign nationals has been felt via their concentrated location choice of mostly high standard rental housing in developing countries. Housing investment by foreign nationals accounted for less than $1 \%$ in Seoul's total housing transactions in 2010, but skilled foreign nationals chose affluent parts of Seoul (Kim et al., 2015). In Chinese large cities such as Beijing, Shanghai and Guangdong, expatriate families have formed ethnic enclaves with strengthened security, high quality amenities, and foreigner-friendly retail shops mostly in gated communities (Chang and Kim, 2016, Wu and Webber, 2004, Breitung, 2012). Their weak engagement in home ownership might be attributable to lack of long-term commitments to the host city (Kim et al., 2015), lack of ethnic connections (Kim, 2017a), their risk-aversion behaviour (Conner et al., 1999), limited access to financial means such as mortgage loans, and/or lack of accumulated capital (Rogers and Koh, 2017). 
Major players tend to be high income earners in the globalising housing market. Sassen (2001) claimed that professionals in globally connected firms, e.g., producer services firms, play a crucial role in global city formation and they are highly paid. These skilled labour flows have been stimulated by MNCs and internationally-focused institutions such as universities and research centres often forming new Argonaut connections (Saxenian, 2006, Kim, 2017b, Kim and Cocks, In Press). However, while FDI flows have been discussed in detail in the literature, understanding of how this geographic business expansion is associated with human capital flows and housing market changes has been, at best, partial.

\section{Urban policy for FDI inflows}

To accelerate inward FDI flows, many developing countries have employed a 'zone' policy, such as free economic zones, development zones, export processing zones, and industrial parks, as seen in a 'zone fever' in China (Yang and Wang, 2008), the Incheon Free Economic Zone in South Korea (Kim and Han, 2012), industrial parks operated by the Jurong Town Coporation in Singapore (Han, 2005) and industrial zones in Vietnam (Kuchiki, 2007). These zones provide for business-friendly environments such as loosened regulatory frameworks, tax incentives for target FDI projects, quality infrastructure, enhanced administrative services and subsidies for industrial land. Governments can better manage industrial activities in these selected sites in providing essential infrastructure such as roads, power and water; also firms can benefit from agglomeration economies (Malmberg and Maskell, 2002). Most zones are designated in industrial land, but the growth of industrial activities has flow-on effects on neighbouring areas including residential and commercial land (Kim and Han, 2014). The focal city of this research, the Suzhou Industrial Park, is also one of the successful development zones in China (Wei et al., 2009, Wei et al., 2013, Pereira, 2004b).

\section{The growth of the housing market in China}

The reform and opening-up policy towards the market economy was adopted by Deng Xiaoping in 1978. There was a "shift from state control of economic production to state regulation of and participation in the market" ( $\mathrm{Ma}$ and $\mathrm{Wu}, 2005$ ). This change has brought fundamental restructuring to property sectors. A marketization policy has facilitated the establishment of property markets in China. The Amendment of Constitution in 1987 established a basis for formation of the land and housing market in which urban land use rights can be tradeable and transferable (Qin and Han, 2013). The state has landownership while the land use rights belong to the buyer. This was a "shift from public (state and collective) ownership of land and its free use to paid land use right with negotiated land use price" ( $\mathrm{Ma}$ and $\mathrm{Wu}, 2005$ ). Since the land use rights were sold first in the Shenzhen Special Economic Zone to foreign investors in 1987 (Lin and Ho, 2005), the commodification of property has established the housing market that had been prohibited under the socialist ideology. According to Wu (2015), the initial stage (1979 - 1998) saw the expansion of the commodity housing market in which work-units (or danwei) played a key role in in-kind housing allocation. However, work-units took a great financial burden to offer housing and there was a long queue for workers to receive housing from their work-unit (Ren, 2013). China's housing market was further facilitated by privatisation of the state-owned houses in the 1990s (Stephens, 2010). In 1998 in-kind housing allocation was abolished; work-units no longer provided housing for workers. Housing mortgage loans, available for better-off households, were introduced to boost the economy $(\mathrm{Wu}, 2015)$. The access to the financial mean has driven aspiration to investment in commodity 
housing with high expectations on asset appreciation, leading to the spiral of housing prices in the 2000s (Wu, 2015).

Many studies have paid attention to rural-to-urban migration and its outcomes in the housing market in Chinese cities. Most migrants were rural peasants without high-level skills and urban registration (or hukou) (Ma and Wu, 2005, Fan, 2002, Fan, 2008). The regional migration has brought significant housing-related urban issues to the local housing market such as excessive demand for housing in urban areas, housing affordability, pocketing land value increases, a polycentric new urban form, and informal settlements (Wu et al., 2013, Qin and Han, 2013, Tian, 2014, Wu, 2015). Foreign nationals have added one more complexity to the housing market, which can be observed in the later stage when globalisation is more progressed.

\section{Housing consumption and hypotheses}

Housing is considered as a normal good that the demand is increasing with greater income. Figure 1 shows indifference curves subject to budget constraints. Along the indifference curve, the level of the utility is the same; higher indifference curves show higher utility. Given the limited financial resources, consumers will choose the optimal point that can maximise their utility. As high income earners have more financial resources, their spending on the housing and other goods is higher than low income earners $\left(\mathrm{H}_{\mathrm{H}}{ }^{*}>\mathrm{H}_{\mathrm{L}}{ }^{*}\right.$ in Figure 1$)$. If the housing subsidy is provided, the budget constraint changes from $B_{H}$ to $B_{H+s}$. The increased financial resource changes the optimal consumption level from $\mathrm{B}\left(\mathrm{H}_{\mathrm{H}}{ }^{*}, \mathrm{O}_{\mathrm{H}}{ }^{*}\right)$ to $\mathrm{C}\left(\mathrm{H}_{\mathrm{H}+\mathrm{S}}{ }^{*}, \mathrm{O}_{\mathrm{H}+\mathrm{S}}{ }^{*}\right)$. At this new optimal point, the consumption level on both housing and other goods are greater than the optimal level without the housing subsidy, but the major increase is found in housing consumption.

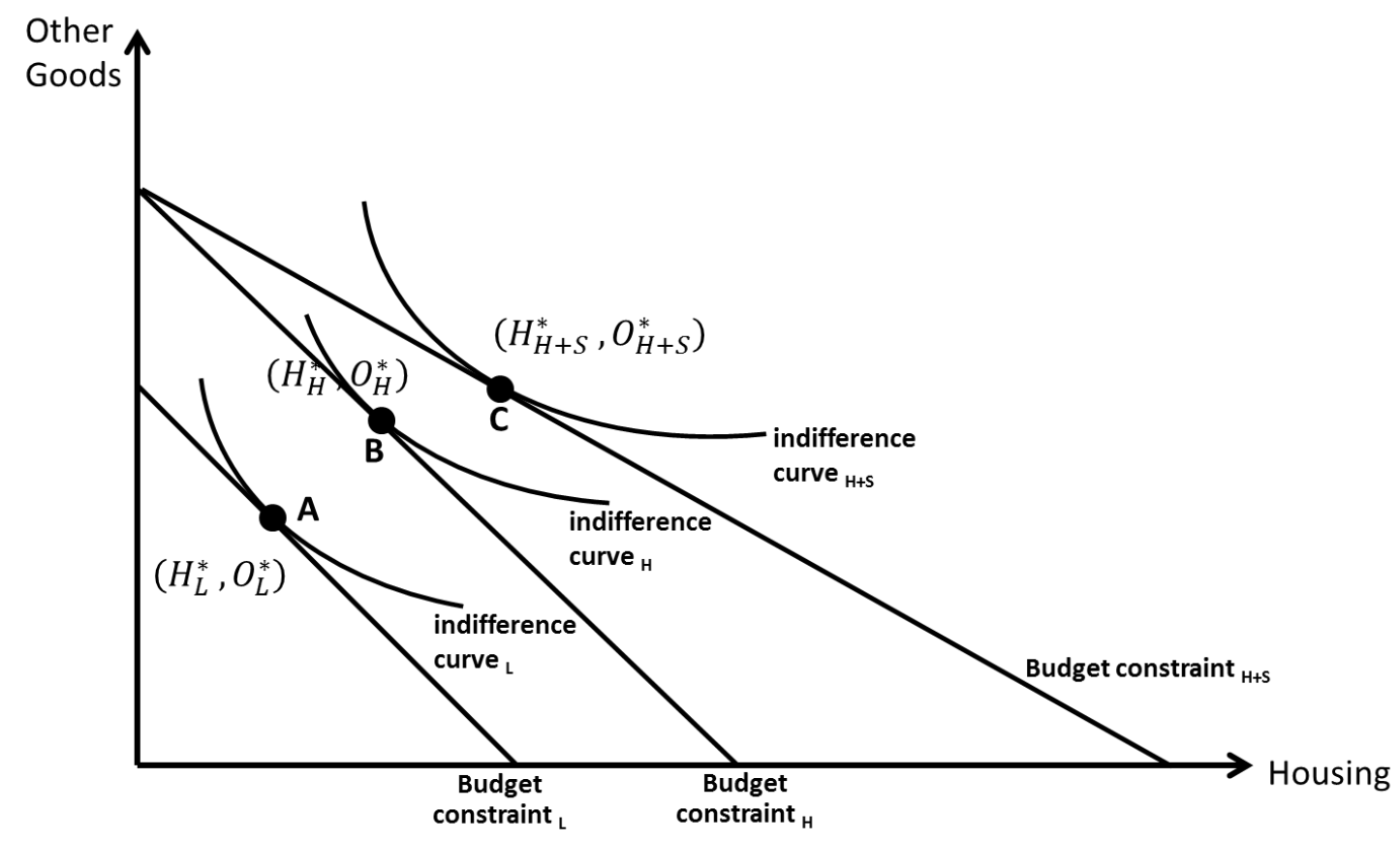

Figure 1 Utility functions and budget constraints for housing consumption: different income levels

Note: $\mathrm{H}$ is housing consumption while $\mathrm{O}$ is consumption on other goods; 
$\mathrm{L}$ is low-income; $\mathrm{H}$ is high income; $\mathrm{S}$ is a housing subsidy; and * means the optimal level to maximise individuals' utility.

Despite significant academic efforts to understand Chinese housing markets, little attention has been paid to the impacts of foreign nationals on the housing market in globalising residential and business environments. With a focus on a fast globalising Chinese city, Suzhou, this paper attempts to fill in a portion of this research gap by answering to the following questions: how are foreign nationals associated with housing price increases in a globalising city? Where and why this impact has been felt in the housing market? To answer to these questions, this research has the following hypotheses:

(1) Income levels of foreign nationals are higher than the locals. As professionals working in a globalising Chinese city, their income levels are high by the international standard. Without competitive salary schemes, expatriate managers would be unwilling to come to the city in a developing country. Higher income earners and households tend to have higher demand for housing consumption. In addition to higher income levels, firms provide housing subsidies for expatriate managers to secure stable, quality living environments in the host city. Economically rational expatriates would choose high-end housing.

(2) Expatriates tend to form ethnic communities for better access to local information, daily goods, public facilities and language-specific facilities and for easy interactions with themselves. Foreign nationals play a crucial role in forming the high-end housing market in a small geographical area.

\section{Methods}

This paper employed two datasets and a Suzhou GIS map for housing market analysis. First, housing price data were collected from a commercial real estate information website, named Soufang Wang ${ }^{1}$, to analyse spatial patterns of housing prices. The website was in operation to promote real estate agencies by providing profiles of the premises. ${ }^{2}$ There were 282 residential complexes identified in the SIP from this website. This research randomly chose one apartment in one residential complex from the website to build the SIP housing price dataset. The information was collected in August,

\footnotetext{
${ }^{1}$ http://esf.suzhou.fang.com/house-a0277/

2 The prices on the website were sellers' asking prices instead of transacted prices. There was no official data about housing prices and detailed transaction information in Suzhou. There might be subtle differences between price information on the commercial website and the market values, but this would not make a significant bias.
} 
2014; housing prices were based on this period. In addition to price data, structural, locational, and neighbourhood characteristics were added. The collected data were used to specify a hedonic price model. Second, this research conducted a questionnaire survey with 508 foreign nationals staying in Suzhou for more than six months for work-related purpose. This survey asked foreign nationals about the name of the residential complex, rent, a housing subsidy, an income level, duration of the stay in Suzhou, and other basic socio-economic, demographic information. Relevant to this survey was a stay of 2 years between 2013 and 2015 in the SIP. The survey was conducted through expats' communities and in public places in 2014. Both online and offline surveys were employed. Survey questionnaires were circulated via expatriate communities such as religious associations, international schools and international universities with high numbers of international staff members. Offline surveys were carried out in both weekdays and weekends in public spaces favoured by foreign nationals such as coffee shops, shopping malls, retail streets, and public plazas (where a flea market was held by expatriate communities). The questionnaire was translated into English, Japanese and Korean to secure participants. The high number of samples at 508 improves the reliability of this research by mitigating potential problems of a sampling bias. Out of the 508 responses, 385 samples specified their residential places. This research relied on a count on the residential complexes where foreign nationals lived to identify ethnic communities. Identified ethnic communities were used as an explanatory variable in the above mentioned hedonic price model.

The two datasets were visualised on a Suzhou GIS map from a commercial GIS company, ESRI China. The base map included key features such as administrative boundaries, roads, canals/lakes, and residential complexes in the entire Suzhou. If the residential complexes collected from the real estate website did not appear on the GIS map, the missing locations were added manually. Although the SIP was a geographical focus, some analyses included Suzhou urban districts to understand the context of the SIP. In addition to the two datasets, to provide in-depth understandings, site visits were made to the SIP ethnic-oriented housing complexes, guided by real estate agencies targeting foreign nationals. An auxiliary visit was made in 2016. Suzhou, located at $80 \mathrm{~km}$ distance from Shanghai, is used in this research as a case study because it has developed two significant FDIoriented industrial parks (i.e., the Suzhou Industrial Park and the Suzhou New District). The use of single case study Suzhou was intended to better answer to 'why' and 'how' research questions (Yin, 2009, Flyvbjerg, 2006). In this research, Suzhou refers to Suzhou urban districts consist of the SIP, the Suzhou New District (SND), the Gusu District (old Suzhou town), the Xiangcheng District, and the Wuzhong District. Administratively, the Suzhou municipality includes regional cities such as Changshu, Zhangjiagang, Kunshan, Wujiang, and Taicang. This Suzhou region extends on a land area of $8488 \mathrm{~km}^{2}$, but the primary focus of this research is the SIP.

\section{The SIP development and the housing market}

The regional growth of Suzhou drew upon Town and Village Enterprises (TVEs), called the Sunan (i.e., Southern Jiangsu) model in the 1970s and the 1980s (Wei et al., 2009, Wei, 2002). However, the 1990s witnessed the decline of TVEs due to vague property rights and backward technologies (Yuan et al., 2014). Instead, the Chinese government attempted to create an internationally competitive industrial city. The Singapore government also sought out strategies to export a Singapore urban development model to Asian countries (Pereira, 2004a, Phelps and Wu, 2009). Thus, the two governments agreed with making a new industrial park in Suzhou in 1992 and the development of 
the SIP began in 1994 (Pereira, 2003). The park was entitled China-Singapore Suzhou Industrial Park; now it is called the Suzhou Industrial Park (or SIP). Singapore government planning agencies, such as Urban Redevelopment Authority (URA), Jurong Town Corporation (JTC), and Housing Development Board (HDB), played an important role in making the SIP plan. In addition to investment in infrastructure and land use plans, the Singapore government provided 'software' transfer programs to train government officials and planners for better management of the SIP (Fook, 2014). As a result, the SIP provided momentum to attract FDI to the extent that it has been significant enough to compete with the top-tier Chinese city, Shanghai. The GDP in Suzhou was 38\% of the Shanghai GDP in 2002, but per capita GDP in Suzhou reached $88 \%$ of Shanghai's, which was the fourth highest in China (Airriess, 2008). The strategy of the Singapore development model was to make use of inward FDI for economic growth (Yeung, 1998). At the beginning, the SIP provided corporate tax incentives for MNCs. For instance, no corporate tax for the first three years and $50 \%$ exemptions for the next following two years. Industrial land was also provided for MNCs at very affordable prices. In the SIP, 84 Global Fortune 500 listed firms were established by 2010 (SIP website). Most MNCs were in advanced IT sectors such as semi-conductors, display industries, precise tools, and computer-related intermediate products forming a cluster for high-tech industries. In the entire Suzhou region, the top origins of FDI were Hong Kong, Taiwan, Japan, Singapore, the USA, and Korea in terms of the actually used amounts of inward FDI in the period 2000-2012 (Suzhou Statistical Yearly Book). In tandem with the growth of inward FDI, the number of foreign nationals is on the increase (Kim, 2015). MNCs dispatch their managers for business control at distance. While the industry base can spread across the Suzhou region, most foreign nationals have chosen to stay in the SIP in favour of liveable environments (Kim and Cocks, 2017).

Another key aspect in the SIP is internationalisation of education, in particular, tertiary education. While the key business area of the SIP is revolving around a development zone co-developed by the two governments on a land area of $80 \mathrm{~km}^{2}$, the southern part of the SIP is allocated for a university town on an area of $25 \mathrm{~km}^{2}$. In this university town, called the Dushu Lake Higher Education Town, there were 28 universities and 191 research institutions in 2013 (www.seid.gov.cn). Some universities provide international tertiary education services, such as Xian Jiaotong-Liverpool University, Monash University and HKU Space Global College, keen to recruit international academic staff and English language teachers as well as international students (Kunzmann, 2015). Many jointprograms offer for dual degrees from the origin university and the Chinese university. The number of foreign nationals in the town increased from 700 to 1500 between 2006 and 2012 (Dushu Lake Higher Education Town Gallery).

In addition, there are adventurous self-employed businessmen in the SIP. The official statistics represent that the number of foreign nationals reached at 14.1 thousand which was $2.1 \%$ of the total SIP population in 2011 (SIP website). This figure is spectacular compared with situations in the 1970s when even rural-to-urban migration was strictly controlled.

While the SIP was located in eastern Suzhou, the Suzhou government has invested in another industrial park, called the Suzhou New District (SND), in western Suzhou. Due to a seemingly unfair competition favourable towards the SND, the Singapore government proclaimed the 'disengagement' with the SIP in 1999 (Pereira, 2004b). 
In line with the urban growth, massive housing construction has been completed. The areas of annual housing completion did not reach to $4 \mathrm{~km}^{2}$ until 2001 in Suzhou. The 2000s witnessed a drastic increase in housing provision. Despite the Global Financial Crisis (GFC) in 2007/8, the average housing construction in the 2000s was much higher than the 1990s (Suzhou Statistical Yearly Book). Despite massive increases in housing supply, housing prices have experienced a more than 7-fold increase since 2000 when the housing price data was available from the commercial real estate website (Figure 2). Even during the GFC, the average housing price did not drop in Suzhou. The 2010s also saw increases in foreign national numbers with the growth in inward FDI in Suzhou, in particular, the SIP.

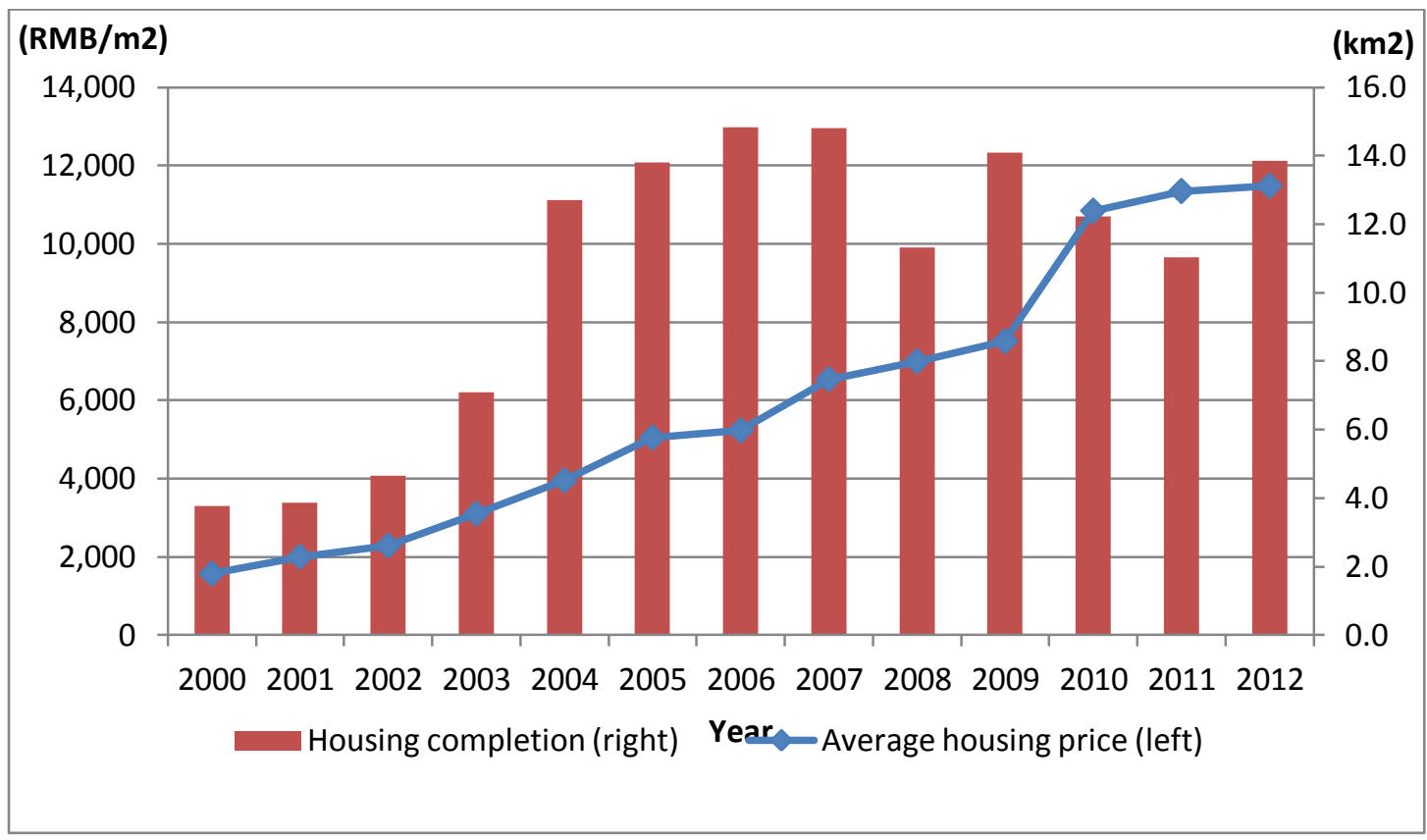

Figure 2 Housing completion and housing prices in Suzhou

Source: www.soufun.com and Suzhou Statistical Yearly Book

\section{A profile of foreign nationals in Suzhou}

This section provides descriptive statistics about Suzhou foreign nationals. First, the duration of the stay was short-term. $61.2 \%$ of the informants replied they have been stayed in Suzhou for less than three years. The average duration of stay at the timing of the survey was 3.5 years. The short duration of stay was possibly because of the recent development of the SIP and corporate human resource management strategies by MNCs. Second, Korea (48.2\%), the USA (12.0\%), and Japan (10.6\%) were top origin countries from the survey. In search of low-cost production sites in Asian countries, Japan and Korea have been active in Chinese cities, in particular, in knowledge-intensive manufacturing sectors. A number of foreign residents from the USA were found in education such as an English teacher. Third, middle-career age groups were most dominant; the majority were in their 30 s $(34.1 \%)$ and 40 s $(40.4 \%)$. Only $8.5 \%$ of the informants were in their 20 s while $14.0 \%$ were in their 50s. Fourth, a substantial number of expatriates were relocated into Suzhou with their children. $39.8 \%$ of the respondents had school-aged children while $22.2 \%$ were singles. Once their children are accompanied, their residential choice would be more complicated. They should find a school, 
facilities for kids and a larger house in a safe place. Fifth, the largest industrial type that the informants worked was knowledge-intensive manufacturing such as IT-related manufacturing (24.8\%), car manufacturing (8.1\%), electronics (7.1\%) and precise machine (6.7\%). Labour-intensive jobs have been disappearing; producer services were not yet mature; but education (13.2\%) and tertiary education/research (6.9\%) sectors had relatively higher numbers of foreign nationals. Expatriates dispatched by MNCs played a significant role in the housing up-market due to their highincome levels and subsidies. For instance, income levels in producer services were the highest and expatriates in manufacturing sectors had also high income levels (Table 1). Income levels in education sectors were lower than the ones of the professionals tied up with MNCs. Foreign nationals in education tended to find a job opportunity individually.

Table 1 Characteristics of foreign nationals by occupation in Suzhou

\begin{tabular}{l|r|r|r|r}
\hline & \multicolumn{1}{|l|}{$\begin{array}{l}\text { Income } \\
\text { (RMB/month) }\end{array}$} & $\begin{array}{l}\text { Housing } \\
\text { subsidy } \\
\text { (RMB/month) }\end{array}$ & $\begin{array}{l}\text { Duration } \\
\text { of stay } \\
\text { (Years) }\end{array}$ & $\begin{array}{l}\text { Ratio of singles } \\
\text { (Marriage status) }\end{array}$ \\
\hline Producer services & 49,828 & 7,341 & 3.0 & $19.4 \%$ \\
ICT manufacturing & 41,644 & 8,456 & 3.0 & $11.4 \%$ \\
Other manufacturing & 43,286 & 8,492 & 3.8 & $13.9 \%$ \\
High education/research & 33,281 & 3,798 & 2.7 & $51.4 \%$ \\
Education & 17,344 & 3,191 & 2.3 & $59.1 \%$ \\
\hline All sectors & 39,000 & 6,400 & 3.5 & $22.2 \%$ \\
\hline
\end{tabular}

In Suzhou, the SIP turned out to be the most favoured urban district by foreign nationals. Table 2 displays the number of respondents and their housing consumption represented in monthly rent. Foreign residents in the SIP paid for the highest rent. The level of the rent was more than double in other regional cities and $47 \%$ higher than the SND (Table 2). High preference on the SIP might be attributable to its liveable environments possibly associated with transplanted Singapore planning practices and FDI-oriented urban development as discussed in the previous section. High demand for high-end housing, supplied in the SIP, has resulted in rental levels much higher than other cities and regions (Table 2).

Table 2 Housing consumption (monthly rent paid by foreign nationals) by district

\begin{tabular}{c|r|r|r|r|r}
\hline & & SIP & SND & Others & \multicolumn{1}{|c}{ All } \\
\hline \multirow{2}{*}{$\mathrm{N}$} & Rent & 353 & 82 & 8 & 443 \\
& Owner & 11 & 0 & 2 & 13 \\
& N.A. & 28 & 19 & 5 & 52 \\
\hline Total & 392 & 101 & 15 & 508 \\
\hline (RMB per month) & Mean & 8403.9 & 5730.0 & 4000.0 & 7829.4 \\
& S.E. & 297.7 & 324.6 & 1029.7 & 251.3 \\
\hline
\end{tabular}

\footnotetext{
* Note: The Kruskall-Wallis test showed the mean values were different between the groups and the results were statistically significant. The Chi-Square value was 27.790; df was 2; and Asymp. Significance was less than 0.001 .
} 


\section{Income, housing subsidies and housing consumption}

The survey result confirms that foreign nationals have higher income levels than the locals. Out of the 508 respondents, 465 foreign nationals specified their income levels. The median income level among foreign nationals was in RMB 20-30 thousand per month ${ }^{3}$; the most frequent income level was in RMB $30-50$ thousand per month, accounting for $25.8 \%$ (Figure 3 ). The average income level was RMB 39,000 in 2014. ${ }^{4}$ By Chinese standard, this income level was high. In Suzhou urban areas, the top 10\% Chinese household income was RMB 23,042 per month; and the average household income was RMB 9,823 per month in 2012 (Suzhou Statistical Yearly Book). The income levels of foreign nationals were as high as approximately four times of the locals.

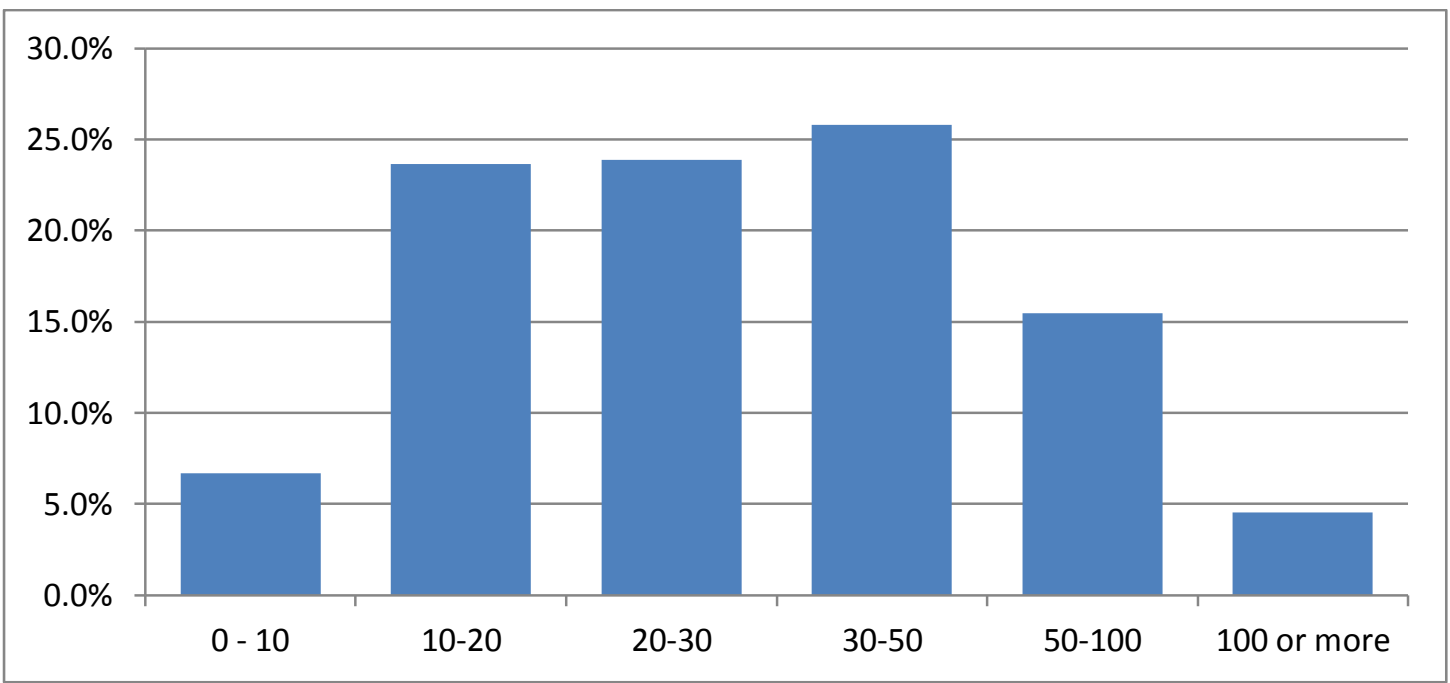

Figure 3 Income distribution of foreign nationals in Suzhou

Unit: thousand RMB.

Note: This figure includes 465 responses who specified their income level.

In addition to higher salary levels, firms provide housing subsidies for expatriate workers. Surveyed expatriates received RMB 6400 for a housing subsidy on a monthly average. More than half of the expatriates received a $100 \%$ (or even higher) housing subsidy for rent (see Appendix 2). Rent was very linear to housing subsidies. Exclusive of responses with zero housing subsidy and No Answer (28.1\%), a very strong correlation was found between rent and the housing subsidy as seen in a high correlation coefficient at 0.93 . Employees try to consume the entire available subsidy for their rental housing. When the amount of the housing subsidy is large, expatriates choose their housing in a better location, fully equipped with furniture and electronics. Often these expatriates over-consume their rental housing more than their needs owing to the provided subsidies. Firms try to guarantee liveable environments at least as similar as their expatriates' hometowns. Housing subsidies are employed to attract and/or retain professional employees in Suzhou where is relatively unknown to foreign nationals. Expensive rental housing is mostly gated for the sake of safety and security.

\footnotetext{
${ }^{3}$ RMB 10,000 was approximately USD 1,600 in 2014.

${ }^{4}$ The average income was calculated using mid-values of each income band. The top income group (RMB 100,000 or more) chose RMB 150,000 for the average calculation.
} 
Foreign nationals tend to choose gated communities to minimise concerns about safety rather than staying mixed with the locals. Some $14 \%$ expatriates received partial housing subsidies ranging from $10 \%$ to $97 \%$ of their rent. Expatriates in small and medium-sized firms and/or in lower positions received smaller amounts of housing subsidies. $16 \%$ of respondents were provided no housing subsidy. Some firms did not provide any subsidy; self-employed foreign nationals had irrelevance to subsidies from the firms.

Predominantly, tenure choice of foreign nationals was rent. Their Suzhou stay was likely in the shortterm. This short duration was tied up with corporate human resources management for expatriates. After a pre-determined period, MNCs send the employees back or relocate to another office. However, 13 respondents or $2.6 \%$ were owner-occupied. Chinese housing policy allows foreign housing ownership if a foreigner has paid for income tax for more than a year and can provide a proof of legal residence. While the vast majority of foreign nationals preferred rent, a small number of foreigners have decided to own a house (apartment). $2.6 \%$ of home ownership seemed low in Suzhou, but it was noteworthy in a sense that foreign nationals started purchasing Chinese housing which was a reversal direction of funds to the direction commonly observed in developed countries such as Australia (Rogers et al., 2015) and Canada (Ley, 2017). Some firms had an internal policy on housing purchase because these firms wanted their employees to come back after their work in China. Home ownership might trigger expatriates to stay in the host city in the long-term.

The average monthly housing rent surveyed online in the SIP was RMB 4127 in the corresponding year. However, surveyed expatriates paid RMB 7800 for their rental housing, which was more than $90 \%$ higher than the SIP average. An interview with an expatriate in a human resources department in a MNC confirmed the high labour costs of expatriate labourers: "Inclusive of regular salaries, housing subsidies, education subsidies for children, and travel allowance, the total cost for expats are more than 10 times higher than local employees even though they are in the same position".

Higher housing consumption can be also found in the size of houses. The most frequent size of foreign nationals' housing was $120-150 \mathrm{~m}^{2}(20.1 \%)$ followed by $80-100 \mathrm{~m}^{2}(18.5 \%)$ and $100-120 \mathrm{~m}^{2}$ (16.9\%). Using mid-values, the estimated average size of housing for foreign nationals was about $130 \mathrm{~m}^{2}$ while the average size in the entire SIP was $120 \mathrm{~m}^{2}$ from the dataset for this research. The results represent that higher income levels and housing subsidies stimulate the move of the budget line in the utility function to higher housing consumption (Figure 1). Residential location choice of foreign nationals has appeared spatially selective. A focus turns into the spatial characteristics of foreign nationals.

\section{Location choice and housing price distribution}

A high concentration of foreign nationals was observed in the core area of the SIP. Table 3 reports top 15 residential complexes where surveyed foreign nationals lived the most. These top 15 apartments accounted for more than $70 \%$ of the total surveyed samples who specified their residences. 10 housing complexes out of the top 15 complexes were located in the SIP. More than $40 \%$ of the foreign nationals lived in the top three residential complexes (Table 3). The foreign nationals in these three residential complexes paid for monthly rent more than RMB 10,000 that was more than double of the average rent in the SIP. 
Moreover, residential complexes were spatially co-located as seen in Figure 4. The north of the Jinji Lake was the core area developed by the Singapore and Chinese governments. The housing upmarkets have been established around the Jinji Lake with a water body of approximately $11.5 \mathrm{~km}^{2}$. The waterfront area had public parks, a theme park, high-end retail shops, the Suzhou Culture and Arts Centre constructed in 2007, and a 300m-high landmark building called Dongfengzimen or 'Oriental Tower'. The first subway line passed through the northern Jinji Lake. The top three most expensive residential complexes were located within $1 \mathrm{~km}$ to the Jinji Lake (Figure 5).

Table 3 Top most popular 15 housing complexes for foreign nationals in Suzhou

\begin{tabular}{|c|c|c|c|c|c|c|}
\hline & Housing complex & Frequency & $\begin{array}{c}\text { Average } \\
\text { Monthly } \\
\text { Rent } \\
\text { (RMB) }\end{array}$ & $\begin{array}{c}\text { Average } \\
\text { Housing } \\
\text { Subsidy } \\
\text { (RMB) }\end{array}$ & $\begin{array}{l}\text { Average } \\
\text { Monthly } \\
\text { Income } \\
\text { (RMB) }\end{array}$ & Location \\
\hline 1 & Linglong wan (Bayside) & 90 & 10,046 & 10,101 & 31,566 & SIP \\
\hline 2 & Tian yu (Horizon Resort) & 41 & 12,050 & 11,925 & 31,875 & SIP \\
\hline 3 & Shanglinglong & 26 & 12,655 & 12,685 & 35,192 & SIP \\
\hline 4 & $\begin{array}{l}\text { Ya Ge Er Wei lai Cheng } \\
\text { (Younger Future City) }\end{array}$ & 19 & 4,405 & 4,467 & 30,000 & SIP \\
\hline 5 & $\begin{array}{l}\text { Zhongtianhupan (Lake } \\
\text { Niew City) }\end{array}$ & 18 & 6,894 & 7,067 & 26,176 & SIP \\
\hline 6 & $\begin{array}{l}\text { Huzuoan (Landmark } \\
\text { Skylight) }\end{array}$ & 13 & 5,217 & 5,430 & 23,333 & SIP \\
\hline 7 & Jinhe Guoji & 10 & 6,357 & 5,643 & 27,778 & SND \\
\hline 8 & $\begin{array}{l}\text { Zhonghaihubin (Lakeside } \\
\text { Palace) }\end{array}$ & 9 & 8,575 & 7,486 & 37,222 & SIP \\
\hline 9 & Yu Huayuan & 8 & 5,513 & 5,929 & 66,250 & SND \\
\hline 10 & He feng ya zhi & 8 & 9,186 & 9,300 & 29,375 & SND \\
\hline 11 & Jinhua yuan & 8 & 6,438 & 5,929 & 35,000 & SND \\
\hline 12 & Zhong yang Jing cheng & 7 & 4,814 & 5,171 & 25,714 & SIP \\
\hline 13 & Mingcheng Huayuan & 6 & 4,150 & 3,817 & 26,347 & SND \\
\hline 14 & Jingli yuan & 6 & 5,833 & 4,750 & 15,811 & SND \\
\hline 15 & $\begin{array}{l}\text { Shuixiang linli (Marina } \\
\text { cove) }\end{array}$ & 6 & 19,900 & 18,100 & 33,875 & SIP \\
\hline & Total & 384 & 6,429 & 7,378 & 34,787 & \\
\hline
\end{tabular}

Note: The location of these housing complexes in the SIP is marked in Figure 4.

This Table includes 385 responses that can be identified for their residential location.

The Jinji Lake area has been transformed into ethnic enclaves. In addition to liveable built environments, these places had language specific-facilities and foreigner-friendly shops such as Korean and European grocery stores/restaurants, dental clinics, medical clinics, language centres and religious spaces that may provide room for ethnic communities. Also, there were bilingual real estate agencies. Due to limited available land in this area, international schools and foreign language schools were not located within this area, but they operated school shuttle buses for easy commuting. Despite some international schools being located $20 \mathrm{~km}$ away, expatriate parents chose 
these ethnic communities for their stay. The high concentration of foreign nationals was often encouraged by the firms. Not only shuttle buses for school-aged children, but employees took shuttle buses for their commuting. $25 \%$ of surveyed expatriates took vehicles operated by the firms for their commuting, which was the second highest commuting mode after private vehicles at $31 \%$. Only $14 \%$ took public transport amongst surveyed expatriates. Although foreign nationals bore relatively long-commuting distance by non-public transport, they tended to stick to ethnic communities in pursuit of better living environments.

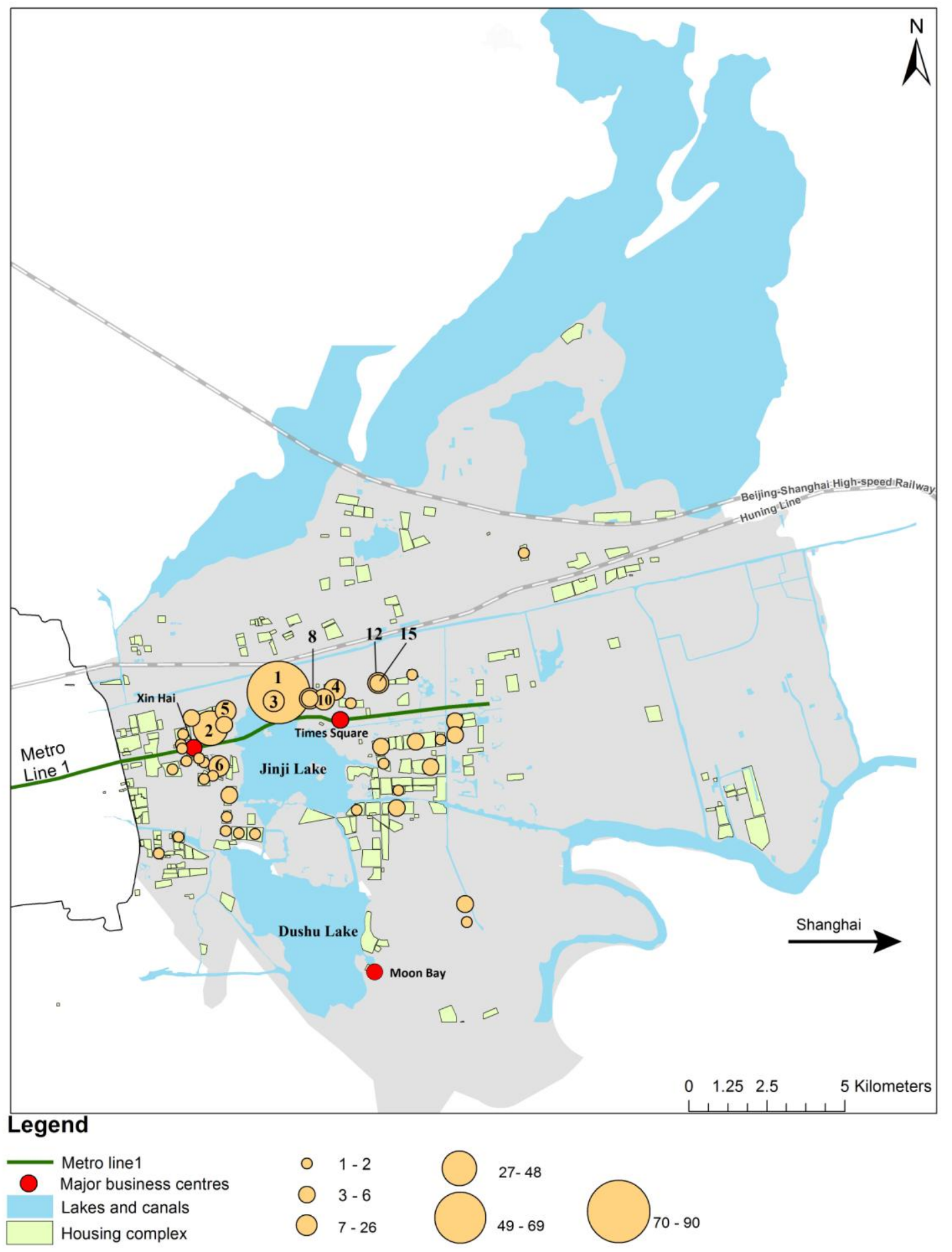

Figure 4 Location distribution of foreign nationals in the SIP from sample responses 
Note: The number represents the housing complex in Table 3.

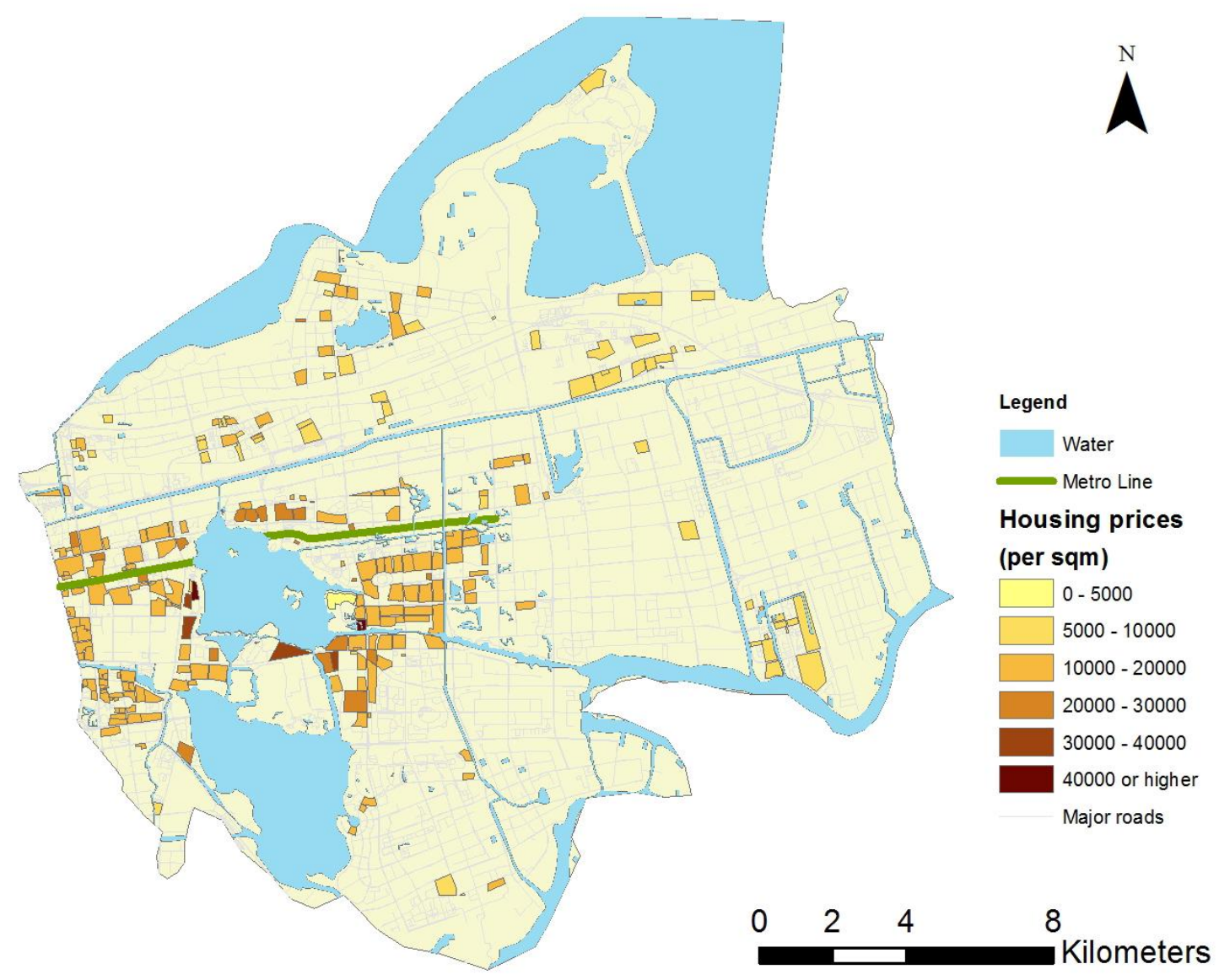

Figure 5 Housing price distribution in the SIP

This section further analyses the association of presence of foreign nationals with housing prices by a hedonic price model which is a typical approach to analyse housing prices showing implicit values of housing attributes (Rosen, 1974). The hedonic price model is multi-regression analysis that includes structural characteristics, location characteristics and neighbourhood characteristics as independent variables. The structural characteristics include physical attributes such as the age, quality of interior design, built-in furniture and size, e.g., the number of bedrooms and bathrooms. Newly constructed houses tend to be more expensive than old ones; larger houses are more expensive than small-sized houses. As explained in a bid-rent curve theory (Alonso, 1964), distance plays a key role in property values. Housing prices (per unit size) decrease with greater distance to the urban core(s) such as the central business district. In the bid-rent curve model, the distance decay was manifest due to the trade-off relationship between transportation costs and land rent. Neighbourhood characteristics mean the quality of the neighbourhood where the house is located. Parks, public facilities, access to the beach, views from the house, school services and presence of 
unpleasant facilities are typical examples to represent neighbourhood characteristics (Huh and Kwak, 1997, Qin and Han, 2013). All these attributes contribute to housing prices. In the multi-regression analysis, the estimated coefficients show the implicit values of the attributes. High quality public facilities contribute to the housing price positively while unpleasant facilities affect housing prices in a negative way. This research asserts that the geographic concentration of foreign nationals (or ethnic communities) is associated with high housing prices.

Figure 5 describes spatial distribution of housing prices in the SIP. As discussed, high housing prices were found around the Jinji Lake. The dataset included the rental price of one sample in the housing complex for Model (1) and the average housing price per square meter for Model (2) and as the dependant variable. In the hedonic price model, structural characteristics included the age calculated by the year of construction and the area in sqm. Location characteristics included the distance to the nearest metro station and distances to the three major urban centres in the SIP, i.e., Xinhai Station, Time Squares, and Moon Bay Station as seen in Figure 4. These major urban centres were identified in the SIP planning documents. In addition to the structural and location characteristics, the ethnic community characteristic was used as a dummy variable. This dummy variable was one for the identified top residential complexes, displayed in Table 3 and Figure 4; otherwise, zero. The linear functional form was taken and the Ordinary Least Square method was used for estimation.

The analysis result is displayed in Table 4. Model (1) has higher explanatory power with the Rsquared value at 0.600 due to the presence of the key structural variable, the size of housing, but the distance decay is rather unclear. Especially the distance variables to the three business centres are unclear while rental prices decrease with greater distance to the metro station. Model (2) only includes the age of the housing for structural characteristics because the dependant variable is the average housing price per sqm. The absence of the size of housing resulted in relatively low explanatory power as seen in the R-squared value at 0.221 . As common hedonic price models, housing prices in the SIP decrease in accordance with the age of the building, the distance to the closest metro station and the distances to major business centres in particular Xinhai Plaza and Moon Bay in the SIP.

The ethnic community dummy variable exhibits that concentrations of foreign nationals have a positive correlation with housing prices for both rental prices and selling prices. The result shows that housing complexes with high concentration of foreign nationals have higher rental prices per month by RMB 2500 and higher housing prices by RMB 4500 per sqm, respectively, on average, which displays a significant gap between ethnic communities and locally-dominant housing communities.

In an income approach of valuation, housing values have a linear relationship with rental income (Whipple, 2006). In the dataset for this analysis, a correlation has been also observed between housing prices and rent (Appendix 1). The correlation coefficient was 0.54 between the two values (Appendix 1). The impact of the influx of affluent expatriate families with housing allowance has appeared directly via the rental market which could be an indirect driver to housing price increases.

Table 4 The result of the hedonic price model analysis 


\begin{tabular}{|c|c|c|c|c|c|c|c|}
\hline & & \multicolumn{3}{|l|}{ Rental price } & \multicolumn{3}{|c|}{ Average housing price per sqm } \\
\hline & & \multicolumn{2}{|c|}{$\begin{array}{l}\text { Unstandardized } \\
\text { Coefficients }\end{array}$} & \multirow{2}{*}{$\begin{array}{c}\begin{array}{c}\text { Standardized } \\
\text { Coefficients }\end{array} \\
\text { Beta } \\
\end{array}$} & \multicolumn{2}{|c|}{ Unstandardized Coefficients } & \multirow{2}{*}{$\begin{array}{c}\text { Standardized } \\
\text { Coefficients } \\
\text { Beta } \\
\end{array}$} \\
\hline & & $\mathrm{B}$ & Std. Error & & B & Std. Error & \\
\hline & Constant & $-1401.230^{\star}$ & $727.250^{*}$ & & $19732.5^{\star \star \star}$ & $973.5^{\star * \star}$ & \\
\hline \multirow[t]{2}{*}{$\begin{array}{l}\text { Structure } \\
\text { Characteristics }\end{array}$} & Area (sqm) & $53.4^{* * *}$ & $2.9^{* * *}$ & $.748^{\star * *}$ & & & \\
\hline & Age (year) & -50.5 & 46.8 & -.046 & $-279.7^{* * *}$ & $77.1^{* * *}$ & $-.207^{* * *}$ \\
\hline \multirow[t]{4}{*}{$\begin{array}{l}\text { Location } \\
\text { Characteristics }\end{array}$} & $\begin{array}{l}\text { DS to } \\
\text { Metro St.(m) }\end{array}$ & $-.183^{\star}$ & $.098^{*}$ & $-.082^{*}$ & $-1.028^{\star * \star}$ & $.166^{\star * *}$ & $-.366^{* * *}$ \\
\hline & $\begin{array}{l}\text { DS to } \\
\text { Xinhai }(m)\end{array}$ & -.073 & .059 & -.129 & $-.246^{\star *}$ & $.099^{\star *}$ & $-.342^{\star *}$ \\
\hline & $\begin{array}{l}\text { DS to } \\
\text { Times Square } \\
\text { (m) }\end{array}$ & .068 & .073 & .106 & $.448^{* * *}$ & $.123^{\star \star \star}$ & $.549^{* * *}$ \\
\hline & $\begin{array}{l}\text { DS to } \\
\text { Moon Bay (m) }\end{array}$ & .006 & .061 & .009 & $-.208^{* *}$ & $.101^{\star *}$ & $-.237^{\star *}$ \\
\hline $\begin{array}{l}\text { Ethnic } \\
\text { community } \\
\text { characteristic }\end{array}$ & $\begin{array}{l}\text { Dummy } \\
\text { (reference = } \\
\text { non-ethnic } \\
\text { community) } \\
\end{array}$ & $2511.4^{\star *}$ & $1019.8^{* *}$ & $.099^{* *}$ & $4513.8^{\star *}$ & $1782.1^{* *}$ & $.139^{* *}$ \\
\hline & & \multicolumn{3}{|c|}{$\begin{array}{l}\mathrm{N}: 269 \\
\mathrm{R} \text {-square: } 0.600\end{array}$} & \multicolumn{3}{|l|}{$\begin{array}{l}\mathrm{N}: 282 \\
\mathrm{R} \text {-square: } 0.221\end{array}$} \\
\hline
\end{tabular}

Note: * statistically significant at the $10 \%$ significance level

** statistically significant at the $5 \%$ significance level

*** statistically significant at the $1 \%$ significance level

\section{Discussions and conclusion}

This paper has shed light on how the influx of foreign nationals, strengthened by corporate crossborder business strategies, has shaped the Chinese housing market. While international inflows in many high-tech industrial clusters such as Silicon Valley, Route 128 in Boston and Science Vale Oxfordshire were not primary drivers to their births and growths (Saxenian, 1983, Valler et al., 2012, Horan and Jonas, 1998), industrialising Chinese cities like Suzhou have made use of inward FDI for knowledge transfer and economic growth in which international expatriate migrants are inevitably associated. The findings from this research suggest that foreign nationals have brought impacts to the housing market by virtue of higher income levels and housing subsidies offered by the MNCs who wants to secure stable living environments for their employees. They have an upward budget line toward higher consumption for housing in the utility function. Consequently, foreign nationals tend to consume more housing than the locals, which was confirmed by results from the rental comparison between the locals and foreign nationals.

This impact has been felt in small geographical areas within highly globalised urban areas as analysed in the hedonic price model. In the case study of the SIP, the top 10 ethnic communities housed more than $70 \%$ of foreign nationals. These highly concentrated ethnic communities were located in the core housing market with easy access to the lakesides and major business centres. These outcomes have been largely driven by corporate offshore production strategies that involve flows of expatriate knowledge workers and their family members. 
Suzhou is rapidly urbanising and globalising, in part, by virtue of government pro-FDI policies manifested in the construction of the SIP and the SND (Kim and Cocks, In Press). The development path of Suzhou displays some characteristics as a global-city region. Typical examples include massive inflows of FDI and presence of foreign nationals, especially high-income professionals, and their ethnic communities. The SIP and partially the SND are growing into a key city in the region that accommodates global capital and professionals. Foreign nationals could afford luxurious houses and amenity facilities available only for the residents. Expatriates, working in a developing country, tend to stay in the short-term due to corporate human resources management strategies. They, therefore, want to secure safe and comfortable living environments instead of being mixed with the locals (Chang and Kim, 2016). In the eyes of housing developers, affluent foreign nationals supported by MNCs are sources for the development of more profitable housing types. From entrepreneur city government perspectives, providing quality living environments is encouraged to attract and/or retain foreign business operations in which expatriates are a significant part (Kim and Cocks, 2017). The SIP has created well-designed city landscapes citywide; gated private housing complexes can provide even more superior-quality living environments. While the city can have well-designed residential areas, the presence of socio-economically high-class foreign nationals might generate 'urban contradictions' such as housing affordability issues for the locals (Saxenian, 1983). Inflows of affluent professionals may 'squeeze out' residents to outer areas as seen in other high-tech Chinese cities such as Beijing, Shanghai, and Shenzhen (Yuan and Hamori, 2014, Miao, 2017, Morrison, 2014). This will require further rigorous analysis to understand the dynamics of the housing market associated with global flows.

\section{References}

AIRRIESS, C. 2008. The geographies of secondary city growth in a globalised China: Comparing Dongguan and Suzhou. Journal of Urban History, 35, 134-149.

ALONSO, W. 1964. Location and land use: towards a general theory of land rent, Cambridge, MA, Harvard University Press.

BREITUNG, W. 2012. Enclave urbanism in China: Attitudes towards gated communities in Guangzhou. Urban Geography, 33, 278-294.

CHANG, J.-I. \& KIM, K.-J. 2016. Everyday life patterns and social segregation of expatriate women in globalizing Asian cities: cases of Shanghai and Seoul. Journal of Housing \& the Built Environment, 31, 545-564.

CONNER, P., LIANG, Y. \& MCLNTOSH, W. 1999. Myths and realities of international real estate investing. Prudential Real Estate Investors, 2-11.

DUNNING, J. H. 1998. Globalization and the New Geography of Foreign Direct Investment. Oxford Development Studies, 26, 47-69.

EDGINGTON, D. W. 1996. Japanese real estate investment in Canadian cities and regions, 1985-1993. The Canadian Geographer 40, 292-305.

FAN, C. C. 2002. The Elite, the Natives, and the Outsiders: Migration and Labor Market Segmentation in Urban China. Annals of the Association of American Geographers, 92, 103-124.

FAN, C. C. 2008. China on the Move : Migration, the State, and the Household, Abingdon, Oxon, Routledge.

FLYVBJERG, B. 2006. Five Misunderstandings About Case-Study Research. Qualitative Inquiry, 12, 219-245.

FOOK, L. L. 2014. Suzhou Industrial Park: Going Beyong a Commercial Project. In: SWEE-HOCK, S. \& WONG, J. (eds.) Advancing Singapore-China Economic Relations. Singapore: Institute of Southeast Asian Studies. 
GUTSTEIN, D. 1990. The new landlords: Asian investment in Canadian Real Estate, Victoria, Porceptic Books.

HAN, S. S. 2005. Global city making in Singapore: a real estate perspective. Progress in planning 64, 69-175.

HARRIS, N. 1997. Cities in a Global Economy: Structural Change and Policy Reactions. Urban Studies, 34, 1693-1703.

HARVEY, D. 1982. The limits to capital, Oxford, Basil Blackwell Publisher.

HE, C. 2003. Location of foreign manufacturers in China: Agglomeration economies and country of origin effects. Papers in Regional Science, 82, 351-372.

HODOS, J. I. 2002. Globalization, regionalism, and urban restructuring: The case of Philadelphia. Urban Affairs Review 37, 358-379.

HORAN, C. \& JONAS, A. E. G. 1998. Governing Massachusetts: Uneven Development and Politics in Metropolitan Boston. Economic Geography, 74, 83-95.

HUH, S. \& KWAK, S.-J. 1997. The choice of functional form and variables in the hedonic price model in Seoul. Urban Studies, 34, 989-998.

JUNG, S., HUYNH, D. \& ROWE, P. G. 2013. The pattern of foreign property investment in Vietnam: The apartment market in Ho Chi Minh City. Habitat International, 39, 105-113.

KIM, H. M. 2015. The role of foreign firms in China's urban transformation: a case study of Suzhou. In: WONG, T.-C., HAN, S. S. \& ZHANG, H. (eds.) Population Mobility, Urban Planning and Management in China. London: Springer.

KIM, H. M. 2017a. Ethnic connections, foreign housing investment, and locality: a case study of Seoul. International Journal of Housing Policy, 17, 120-144.

$\mathrm{KIM}, \mathrm{H}$. M. 2017b. A profile of foreign nationals in a globalising second-tier Chinese city, Suzhou. In: PRESENZA, A. \& SHEEHAN, L. (eds.) Geopolitics and Strategic Management in the Global Economy. Hershey: IGI Global.

KIM, H. M. \& COCKS, M. 2017. The role of Quality of Place factors in expatriate international relocation decisions: A case study of Suzhou, a globally-focused Chinese city. Geoforum, 81, 1-10.

KIM, H. M. \& COCKS, M. In Press. Urbanisation and Globalisation: An Overview of Modern Suzhou Development In: HAN, S. S. \& LIN, W. (eds.) Essays on Healthy future cities. China Architecture Industry Press.

KIM, H. M. \& HAN, S. S. 2012. City profile: Seoul. Cities, 29, 142-154.

KIM, H. M. \& HAN, S. S. 2014. Inward foreign direct investment in Korea: location patterns and local impacts. Habitat International, 44, 146-157.

KIM, H. M., HAN, S. S. \& O'CONNOR, K. B. 2015. Foreign housing investment in Seoul: origin of investors and location of investment. Cities, 42, 212-223.

KUCHIKI, A. 2007. Agglomeration of exporting firms in industrial zones in northern Vietnam: players and institutions. In: TSUJI, M., GIOVANNETTI, E. \& KAGAMI, M. (eds.) Industrial Agglomeration and New Technologies: A Global Perspective. Cheltenham: Edward Elgar Publishing.

KUNZMANN, K. R. 2015. Urbanization in China: learning from Europe? A European perspective. International Journal of Urban Sciences, 19, 119-135.

LEY, D. 2017. Global China and the making of Vancouver's residential property market. International Journal of Housing Policy, 17, 15-34.

LIM, L. C., ADAIR, A. \& MCGREAL, S. 2002. Capital flows into the Singapore real estate market: an analysis of the land sales program. Journal of Real Estate Literature, 10, 265-277.

LIN, G. C. S. \& HO, S. P. S. 2005. The state, land system, and land development processes in contemporary China. Annals of the Association of American Geographers, 95, 411-436.

LIZIERI, C. 2009. Towers of capital: office markets \& international financial services, Chichester, U.K. ; Ames, lowa, Wiley-Blackwell Pub. 
MA, L. J. C. \& WU, F. 2005. Restructuring the Chinese city. In: MA, L. J. C. \& WU, F. (eds.) Restructuring the Chinese city: changing society, economy and space. London ; New York: Routledge.

MALMBERG, A. \& MASKELL, P. 2002. The Elusive Concept of Localization Economies - Towards a Knowledge-based Theory of Spatial Clustering. Environment and Planning A, 34, 429-449.

MIAO, J. T. 2017. Housing the Knowledge Economy in China: An Examination of Housing Provision in Support of Science Parks. Urban Studies, 54, 1426-1445.

MORRISON, N. 2014. Building talented worker housing in Shenzhen, China, to sustain place competitiveness. Urban Studies, 51, 1539-1558.

PEREIRA, A. A. 2003. State Collaboration and Development Strategies in China: The case of the ChinaSingapore Suzhou Industrial Park, London and New York, RouteledgeCurzon.

PEREIRA, A. A. 2004a. State entrepreneurship and regional development: Singapore's industrial parks in Batam and Suzhou. Entrepreneurship \& Regional Development, 16, 129-144.

PEREIRA, A. A. 2004b. The Suzhou Industrial Park Experiment: the case of China-Singapore governmental collaboration. Journal of Contemporary China, 13, 173-193.

PHELPS, N. A. \& WU, F. 2009. Capital's search for order: Foreign direct investment in Singapore's overseas parks in Southeast and East Asia. Political Geography, 28, 44-54.

QIN, B. \& HAN, S. S. 2013. Emerging Polycentricity in Beijing: Evidence from Housing Price Variations, 2001-05. Urban Studies, 50, 2006-2023.

REN, X. 2013. Urban China, Cambridge, UK; MA, USA, Polity.

ROGERS, D. \& DUFTY-JONES, R. 2015. 21st-Century Ausralian Housing: New Frontiers in the AsiaPacific. In: DUFTY-JONES, R. \& ROGERS, D. (eds.) Housing in 21st-Century Australia: People, Practices and Policies. England and USA: Ashgate.

ROGERS, D. \& KOH, S. Y. 2017. The globalisation of real estate: The politics and practice of foreign real estate investment. Taylor \& Francis.

ROGERS, D., LEE, C. L. \& YAN, D. 2015. The Politics of Foreign Investment in Australian Housing: Chinese Investors, Translocal Sales Agents and Local Resistance. Housing Studies, 30, 730748.

ROSEN, S. 1974. Hedonic Prices and Implicit Markets: Product Differentiation in Pure Competition. Journal of Political Economy, 34-55.

SAXENIAN, A. 1983. The urban contradictions of Silicon Valley: regional growth and the restructuring of the semiconductor industry. International Journal of Urban \& Regional Research, 7, 237.

SAXENIAN, A. 2006. The new argonauts : regional advantage in a global economy, Cambridge, Mass., Harvard University Press.

STEPHENS, M. 2010. Locating Chinese Urban Housing Policy in an International Context. Urban Studies, 47, 2965-2982.

TIAN, L. 2014. Property rights, land values and urban development: betterment and compensation in China, Edward Elgar Publishing.

VALLER, D., PHELPS, N. A. \& WOOD, A. M. 2012. Planning for growth? The implications of localism for 'science Vale', Oxfordshire, UK. Liverpool University Press (UK).

WEI, Y. D. 2002. Beyond the Sunan model: trajectory and underlying factors of development in Kunshan, China. Enviornment and Planning A, 34, 1725-1747.

WEI, Y. D., YUAN, F. \& LIAO, H. 2013. Spatial Mismatch and Determinants of Foreign and Domestic Information and Communication Technology firms in Urban China. The Professional Geographer, 65, 247-264.

WEI, Y. H. D., LU, Y. \& CHEN, W. 2009. Globalizing regional development in Sunan, China: Does Suzhou Industrial Park fit a neo-Marshallian district model? Regional Science, 43, 409-427.

WEI, Y. H. D., ZHOU, Y., SUN, Y. \& LIN, G. C. S. 2012. Production and R\&D networks of foreign ventures in China: Implications for technological dynamism and regional development. Applied Geography, 32, 106-118.

WHIPPLE, R. T. M. 2006. Property valuation and analysis, Pyrmont, N.S.W., Lawbook. 
WU, F. 2015. Commodification and housing market cycles in Chinese cities. International Journal of Housing Policy, 15, 6-26.

WU, F. \& WEBBER, K. 2004. The rise of "foreign gated communities" in Beijing: Between economic globalization and local institutions. Cities, 21, 203-213.

WU, F., ZHANG, F. \& WEBSTER, C. 2013. Informality and the Development and Demolition of Urban Villages in the Chinese Peri-urban Area. Urban Studies, 50, 1919-1934.

YANG, D. Y.-R. \& WANG, H.-K. 2008. Dilemmas of Local Governance under the Development Zone Fever in China: A Case Study of the Suzhou Region. Urban Studies, 45, 1037-1054.

YANG, Y. R. \& HSIA, C. J. 2007. Spatial clustering and organizational dynamics of transborder production networks: a case study of Taiwanese information-technology companies in the Greater Suzhou Area, China. Environment and Planning A, 39, 1346-1363.

YEUNG, H. W.-C. 1998. The political economy of transnational corporations: a study of the regionalization of Singaporean firms. Political Geography, 17, 389-416.

YIN, R. K. 2009. Case study research : design and methods, Thousand Oaks, Calif., SAGE.

YUAN, F., WEI, Y. D. \& CHEN, W. 2014. Economic transition, industrial location and corporate networks: remaking the Sunan model in Wuxi City, China. Habitat International, 42, 58-68.

YUAN, N. \& HAMORI, S. 2014. Crowding-out effects of affordable and unaffordable housing in China, 1999-2010. Applied Economics, 46, 4318-4333.

Dushu Lake Higher Education Town, www.seid.gov.cn

National Bureau of Statistics of China, http://data.stats.gov.cn/

SIP website, http://www.sipac.gov.cn/english/

Soufang website, http://esf.suzhou.fang.com/house-a0277/ 


\section{Appendix 1. Rent and housing prices in the SIP}

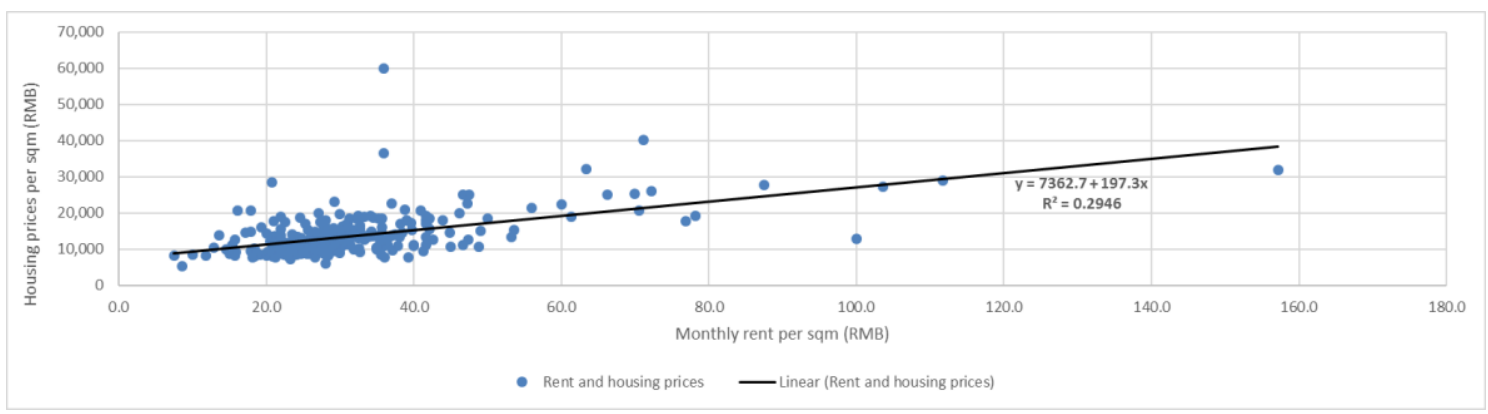

Note: The correlation coefficient is 0.54 .

\section{Appendix 2. Housing subsidies and rent}

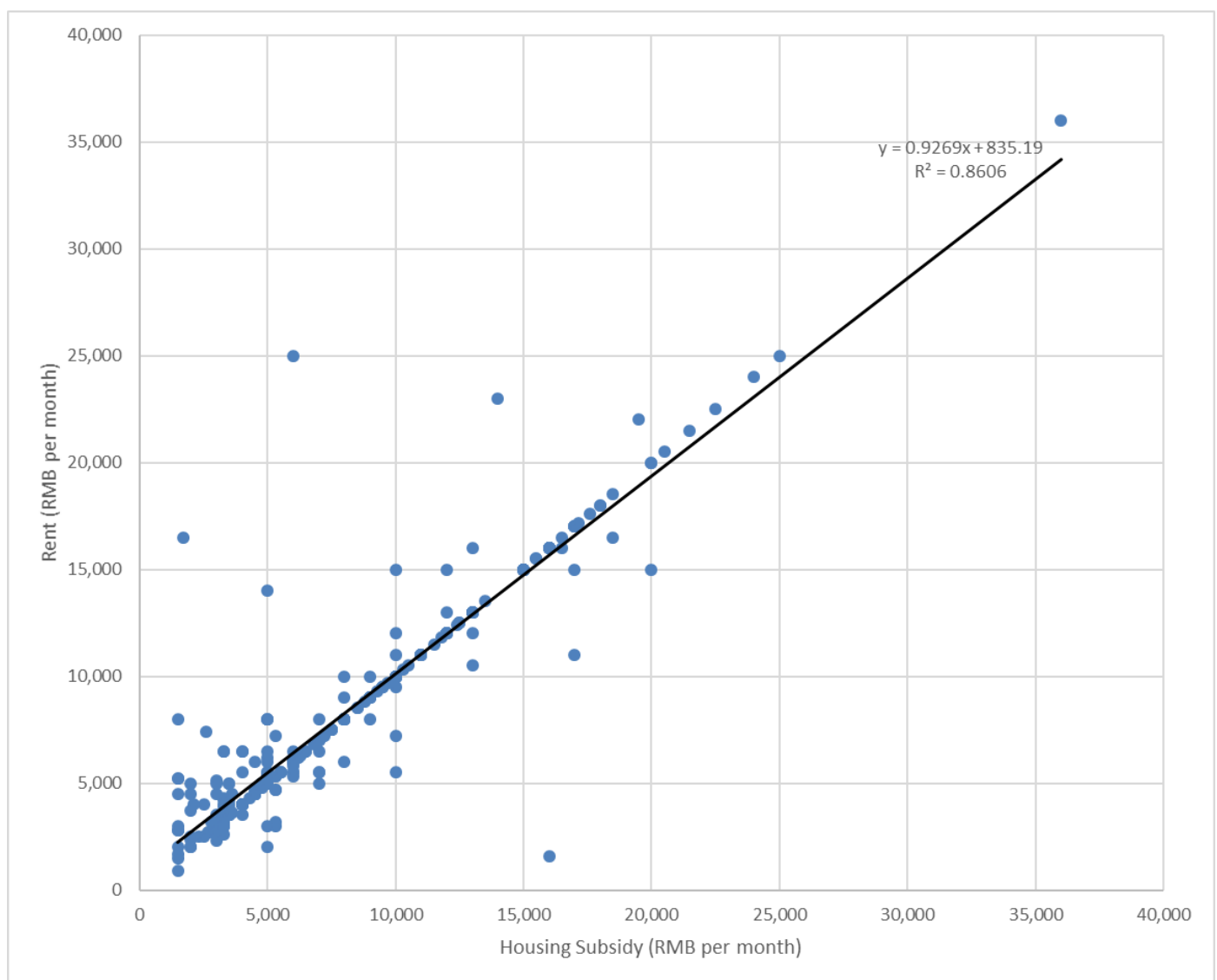

Note: This graph used 361 responses that received housing subsidies. '0' subsidy and No Answer responses were excluded. The correlation coefficient is 0.93 


\section{University Library}

\section{- M M N E R VA A gateway to Melbourne's research publications}

Minerva Access is the Institutional Repository of The University of Melbourne

Author/s:

Kim, HM

Title:

The influx of high-income foreign nationals and the housing market in a developing country: a case study of Suzhou Industrial Park, China

\section{Date:}

2018-12-01

\section{Citation:}

Kim, H. M. (2018). The influx of high-income foreign nationals and the housing market in a developing country: a case study of Suzhou Industrial Park, China. JOURNAL OF HOUSING AND THE BUILT ENVIRONMENT, 33 (4), pp.767-788. https://doi.org/10.1007/ s10901-017-9585-y.

Persistent Link:

http://hdl.handle.net/11343/282620 